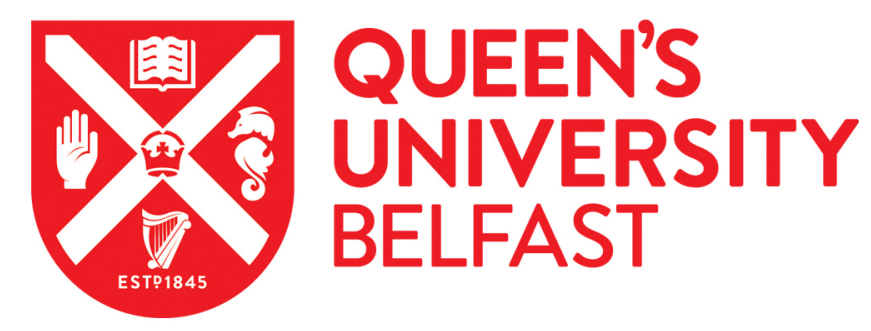

\title{
Systemic Representation: Democracy, Deliberation, and Nonelectoral Representatives
}

Kuyper, J. W. (2016). Systemic Representation: Democracy, Deliberation, and Nonelectoral Representatives. American Political Science Review, 110(2), 308-324. https://doi.org/10.1017/S0003055416000095

Published in:

American Political Science Review

Document Version:

Peer reviewed version

Queen's University Belfast - Research Portal:

Link to publication record in Queen's University Belfast Research Portal

Publisher rights

(c) American Political Science Association 2016. This work is made available online in accordance with the publisher's policies. Please refer to any applicable terms of use of the publisher.

\section{General rights}

Copyright for the publications made accessible via the Queen's University Belfast Research Portal is retained by the author(s) and / or other copyright owners and it is a condition of accessing these publications that users recognise and abide by the legal requirements associated with these rights.

Take down policy

The Research Portal is Queen's institutional repository that provides access to Queen's research output. Every effort has been made to ensure that content in the Research Portal does not infringe any person's rights, or applicable UK laws. If you discover content in the Research Portal that you believe breaches copyright or violates any law, please contact openaccess@qub.ac.uk. 


\section{Systemic Representation:}

\section{Democracy, Deliberation, and Non-Electoral Representatives}

At local, national, regional, and global levels of governance, non-electoral representatives gain presence and prominence through performative claim-making and the mobilization of constituencies. ${ }^{1}$ Individuals, neighborhood boards, social movements, lobby groups, media outlets, religious orders, corporations, non-governmental organizations (NGOs), and myriad other actors take it upon themselves to speak for others in diverse contexts with various effects. Because non-electoral representatives are neither authorized by, nor accountable to, the spatiallybound constituencies that compose national democracies, their existence raises deep theoretical questions about the way we understand the nature of political representation outside the traditional framework of electoral democracy. Given this situation, how can we assess the democratic legitimacy of non-electoral representatives? And, more fundamentally, is 'democracy' the appropriate standard by which to evaluate these agents?

Two related claims are advanced and sustained in this article. First, I contend that nonelectoral representatives should be judged by their position in a wider system. A democratic system is composed of three key elements: the empowered space, the public space, and

${ }^{1}$ The term 'non-electoral representative' designates all actors who are not elected through the national or European Union (EU) electoral framework yet make representative claims. See Urbinati and Warren $(2008,388)$. 
transmission belts between the two. ${ }^{2}$ Only non-electoral representatives in the empowered space actually trigger the need for democratic legitimation (Abizadeh 2012). This is because it is the exercise of coercive political power that must be democratically legitimated by those subjected to rules, laws, and decisions being implemented. Non-electoral representatives in the public space do not stand in need of democratic legitimation because they are unable to exercise coercive rule-making. While actors in both the empowered and public spaces should not harm those they affect, a duty of democratic consideration does not hinge on affectedness. Recent scholarship has glossed over the different spaces occupied by non-electoral representatives within democratic systems and the varied normative standards that turn on those positions.

Second, I submit that deliberative democracy offers a better theoretical framework to evaluate non-electoral representatives compared to alternatives proffered in the current literature. Precisely because these actors articulate representational claims and mobilize constituencies through discursive practice, deliberative democracy offers a robust theoretical toolkit. I employ the notion of deliberative capacity in which inclusive, authentic, and consequential deliberation across an interconnected system becomes the yardstick of democracy (Dryzek 2009). These criteria are operationalized to evaluate how non-electoral representatives in the empowered space should act. It also provides insight into the way non-electoral representatives in the public space can be internally undemocratic, or act in non-deliberative ways, yet still fulfill democratic functions within the broader system. As becomes clear, the ability of actors in the public space to

${ }^{2}$ While much recent scholarship has spoken about 'deliberative systems' (Parkinson and Mansbridge 2012), I follow Mark Warren (2012) and instead focus on 'democratic systems'. This is because democratic systems entail features which are not merely deliberative (voting, contestation, etc.). 
supplement systemic deliberation, oppose non-deliberative moments in the empowered space, or seek systemic reflexivity when anti-deliberative norms become ingrained are key to democratic quality.

The theoretical framework of systemic representation I develop thus depicts the elemental parts of a democratic system and assigns normative standards according to the space occupied by the non-electoral representative. I argue that assessments of democratic legitimacy must go beyond the representative-constituency dyad and instead occur at the systemic level by reference to subjected actors. This helps mitigate a central concern underpinning recent work on political representation which highlights how non-electoral representatives invoke constituencies through claim-making, but also recognizes the potential for framing (and even manipulation) through this mobilization (Disch 2011).

In order to gain traction on key claims, I undertake a case study of the AntiCounterfeiting Trade Agreement (ACTA) which sought to alter intellectual property (IP) rights law across 38 countries. Negotiations on this multilateral trade deal began in 2006 and unraveled in 2012. I outline the interrelated system of states, international organizations (IOs), and nonstate actors in this process, and explore the variegated positions of non-electoral representatives. I apply the criteria of deliberative capacity to unpack the democratic legitimacy of those in the empowered space and also show how non-electoral representatives in the public space contributed to a more legitimate democratic system.

Because the arguments in this article are mainly theoretical, this analysis is best understood as an illustrative study which identifies how non-electoral representatives can be democratically evaluated within a system. The case was selected because it cuts across and beyond national borders. This helps to make clear how democratic systems emerge in a world of 
deep interdependence and demonstrates how the transnational exercise of coercive power can trigger democratic demands for legitimation. The case provides a strong rebuke to methodological nationalists who contend that the boundaries of democracy remain coterminous with national territorial borders. Moreover, because transnational politics is relatively lacking in terms of both institutional norms and a well-defined demos, the ways in which representational claim-making fosters communicative practices and invokes constituencies becomes vital to understand (Dryzek and Niemeyer 2008).

The article moves forward in five steps. In the first section, I trace developments in the concept of political representation and make links with democratic theory. This situates the recent theoretical and empirical interest in non-electoral representatives, especially in relation to the constructivist turn in representational theory. Next, I argue that non-electoral representatives should be evaluated by their position within a system; I flesh out the ongoing systemic phase in deliberative theory and operationalize deliberative capacity so it can be employed to evaluate the democratic credentials of actors within a system. In the third and fourth sections, I briefly outline the democratic system which constituted the ACTA negotiations drawing distinctions between the empowered and public spaces. I then apply the criteria of deliberative capacity to elucidate how empowered non-electoral representatives failed in their democratic duty, whereas some public non-electoral representatives managed to turn democratic impulses into wider systemic changes. I conclude by discussing how analysis of non-electoral representatives helps discern strengths and weaknesses in the emergent literatures on democratic systems and the constructivist turn in political representation. 


\section{POLITICAL REPRESENTATION AND DEMOCRACY}

Although discussions concerning representation and democracy have a rich tradition, most research linking the concepts has focused on the nexus of representation and electoral democracy. ${ }^{3}$ Hanna Pitkin $(1967,140)$, in her influential account, stated that representatives should 'make present again' the views of the citizenry. To ensure congruence, elections enable a constituency (a predefined demos) to authorize and hold accountable their representatives.

Pitkin's 'standard account' of representation has bordered upon hegemonic in political science. As Andrew Rehfeld $(2006,3)$ notes, subsequent work on political representation "only expanded, without seriously questioning, Pitkin's fundamentals". For instance, Anne Phillips (1995), Iris Marion Young (2000), Suzanne Dovi (2002) and Simon Chauchard (2014) have probed how historically-excluded groups could be given political presence in liberal democracies through representatives that descriptively mirror those groups. Jane Mansbridge $(2003 ; 2009)$ has examined how the standard account (what she calls 'promissory representation') is supplemented by anticipatory, gyroscopic, and surrogate forms of representation. ${ }^{4}$ Although Mansbridge (2003) clearly unpacks the deliberative and plural nature of representation in these cases, electoral and liberal democratic institutions still provide the undergirding structure (c.f. Saward 2014, 732).

The standard account has come under increased scrutiny in recent years. In a pointed criticism, Rehfeld $(2006,3)$ argues that by tying representation with the conditions that render it legitimate (electoral democracy), "the standard account is doing double duty: not only does it tell us when a representative is legitimate or democratic, it also purportedly tells us when a person is

${ }^{3}$ The delegate/trustee debate focuses almost exclusively on electoral representation.

${ }^{4}$ For a sustained discussion and critique, see Rehfeld (2009). 
a political representative at all". This is problematic because many forms of representation are best described as non-electoral and, potentially, non-democratic (Urbinati and Warren 2008, 402). Spiritual guides, leaders of non-democratic states, interest groups, the recent diffusion of citizen forums or minipublics (such as citizens' juries, deliberative polls, and consensus conferences; see Brown 2006), and many other examples suggest that non-electoral representation is a pervasive and persistent phenomenon. Yet in all these instances, actors claim to represent the interests, ideas, and discourses of others without the authorization or accountability offered by elections. Although it certainly remains important to understand electoral forms of representation, it is theoretically necessary to decouple representation from electoral democracy to understand how non-electoral representation should be understood and evaluated.

\section{The Constructivist Turn and Non-Electoral Representation}

In order to make this step, the recent literature on political representation has undergone a constructivist turn (Ankersmit 2002; Disch 2011). This turn rests on two foundations: first, representation should be conceptualized as an ongoing process of performative claim-making (Saward 2010); second, representation is constitutive of popular power rather than the other way around (Näsström 2015). To operationalize these conditions, Michael Saward (2010) has argued that representative claims involve five components: a maker of representations puts forward a subject which stands for an object which is related to a referent and is offered to an audience. Claim-making also invokes a constituency which is the set of actors that the 'subject' speaks for (sometimes, though not always, the referent). Through a continual process of discursive claim- 
making, constituencies and audiences are actualized by representatives who identify, call forth, organize, and shape latent interests.

Although the constructivist turn sheds light on how electoral representatives can depict their constituency in certain ways and speak for people beyond their formal territorial bounds, this article focuses on non-electoral representative claim-making. Non-electoral representation is an extensive category covering all actors who are not elected through the national or EU electoral framework yet make representative claims. This includes actors who are appointed to their position such as judges, administrators, and diplomats, or leaders of membership-based organizations that assign their own leaders. ${ }^{5}$ I take the diverse category of non-electoral representation as the object of study because, as will become clear, it is the space occupied in the broader system that is paramount in making normative evaluations.

Because the constructivist turn rejects the implicit link between elections and representational legitimacy, many scholars have insisted on looking for alternative sources of democratic legitimacy for non-electoral representatives. There are many examples in the literature following this trend. Saward $(2009,21)$, for instance, claims that the democratic potential of non-electoral representation hinges upon authenticity: the apparent and constant responsiveness of representatives to those being represented. Laura Montanaro $(2012,1094)$ argues that claim-making brings two constituencies into being: the group empowered by the claim to exercise authorization and demand accountability, and the group (potentially) affected by collective decisions. Non-electoral (or, in her conceptualization, self-appointed)

${ }^{5}$ These actors would be ruled out by definitional fiat if the nomenclature of self-appointed or self-authorized representation were adopted. See, for instance, Montanaro (2012) or Urbinati and Warren $(2008,403-5)$. 
representatives are democratic when the affected group is the same as the empowered group. Self-appointed representatives, Montanaro $(2012,1098)$ avers, therefore "have their greatest value when they fill the gaps in electoral representation, narrowing the difference between formal voting equality and what is normatively required by the affected interests standard." Similarly, Sofia Näsström (2015) argues that non-electoral representatives can foster democratic legitimacy if they help to generate political equality among affected citizens.

While such recent work has been productive and insightful, there are two main problems. First, non-electoral representatives are treated as a singular class of agents who either require or evade the need for democratic legitimation. Saward (2009; 2014), Macdonald (2008), Montanaro (2012), Näsström (2015) and numerous others contend that, because non-electoral representatives (potentially) affect others, they require democratic legitimation. In contrast, Ruth Grant and Robert Keohane (2005) and Jennifer Rubenstein (2014) suggest that international nonelectoral representatives should have their power checked but do not see the need for democratic curtailment. Given the incredibly wide range of tasks performed by non-electoral representatives, applying the same standards to all agents seems problematic. While some non-electoral representatives wield very substantial forms of public power, others are limited to advisory or consultative status. Democratically speaking, these empirical differences require theoretical nuance.

Second, the current literature still relies heavily upon the standard model of electoral representation to generate democratic standards for non-electoral representatives. For instance, after discussing the history of electoral representation, Mark Brown (2006) inductively arrives at authorization, accountability, expertise, participation, and resemblance as the appropriate standards by which to judge citizen forums and minipublics. Saward (2009) also discusses how 
elected representatives provide affected parties with democratic choice, consent, identification, and accountability. Saward $(2009,8)$ specifically states that "non-elective representative claims can enact principles that also figure heavily with regard to elections”. Terry Macdonald (2008) and Montanaro (2012) both take authorization and accountability as the appropriate standards to judge non-electoral representatives and then search for a range of mechanisms which can substitute for voting. As non-electoral representatives are active in the constitution of constituencies - including mobilization and framing - this undermines the utility of authorization and accountability as democratic mechanisms because representatives themselves shape the preferences and interests of constituencies. Lapsing back onto electoral democracy to generate normative standards therefore risks compromising the constructivist turn.

The next section provides a response to both issues raised. I argue that non-electoral representatives should be judged by their position in a democratic system. Only those agents in the empowered space who exercise coercive forms of rule-making require democratic legitimation. This entails moving away from 'all-affectedness' as the trigger for democratization and toward 'all-subjectedness'. Non-electoral representatives in the public space who do not exercise coercive rule-making avoid the need for democratic legitimation. However, agents in the public space can still fare better or worse in terms of their democratic contribution to a system. This distinction between empowered and public spaces (based on the all-subjectedness principle) is required to maintain conceptual coherence of a democratic system and to help identify which agents should be held to demanding democratic standards. Turning from electoral democracy, I stipulate deliberative capacity - inclusivity, authenticity, and consequentiality - as a normatively appropriate measure of democratic legitimacy. I operationalize deliberative capacity for those non-electoral representatives in the empowered space. I also outline criteria for 
those agents in the public space which may violate standards of deliberative democracy in a strict sense, but can have positive democratizing effects in other ways.

\section{SYSTEMIC REPRESENTATION AND DELIBERATIVE CAPACITY}

\section{Deliberative Democracy and Representation}

Deliberative democracy - the notion that free and non-coercive deliberation should guide public policy and law making - has dominated democratic and political theory over the past two decades. During this time, three distinct phases can be distinguished. Early work had a 'macro' complexion: theorists such as Seyla Benhabib (1996), Jürgen Habermas (1996), and John Dryzek (1996) explored how deliberation could occur within civil society. These scholars argued that an unconstrained and distortion-free public sphere could provide an appropriate locus for public debate free from corporate and state domination. Subsequent to this work, theorists and practitioners turned toward 'micro' analysis of deliberation: parliaments, courts, and minipublics provided small-scale venues to test how individuals deliberate under different conditions and the effects upon preference transformation (Bohman 1998). Minipublics in particular have been established to understand how a small (representative) cross-section of society can deliberate under ideal circumstances (Brown 2006).

Although macro and micro approaches have helped advance the deliberative democracy literature, recent work has sought to reconcile these strands through 'systemic' analysis (Parkinson and Mansbridge 2012). The core idea behind this third phase is that deliberation should be thought to take place across a comprehensive system incorporating a range of 
differentiated but interconnected spaces. By looking at everyday talk in the household, internet forums, media outlets, workplaces, bureaucracies, expert committees, parliaments and a host of other venues, we can begin to understand how arguments are made, tested, and recalibrated over time. Because no single institution can be perfectly designed to uphold all the different features of deliberative democracy, we should foster deliberation across a system that ties together formal institutions, civil society, and networks of individuals. While most work in this new phase takes the nation-state as its primary focus, the systemic view can be applied to any setting with interconnected institutions.

The interconnections between micro and macro arenas have also called into question the nature and scope of legitimate action within deliberative theory. Although bargaining, selfinterest, and rhetoric have historically been abrogated as antithetical to truthful and authentic deliberation, the systemic view asks how these actions contribute to the broader setting (Dryzek 2010). We should be attuned to the possibility that non-deliberative actions in one venue promote deliberation elsewhere. Conversely, deliberation in one location might undermine the democratic quality of the overall system that deserves consideration (Parkinson and Mansbridge 2012). Probing exactly how and when non-deliberative acts facilitate or hamper democratization is vital in stopping the systemic phase from justifying the status quo.

This systemic phase of deliberative democracy also enables connections with the constructivist turn in representation theory. Nadia Urbinati (2000) has persuasively argued that representation is an essential component of democratic governance. This is because representatives provide critical distance for citizens from the direct process of rule-making and thus enable political space for deliberation. Moreover, because representative claim-making 
shapes the preferences and interests of constituencies and audiences, it is crucial to determine how representation impacts deliberation between different agents (Disch 2011).

Although much of this systemic work has developed within deliberative theory, the remainder of this article will instead talk about democratic systems. This is because, as noted above, deliberation is one feature that contributes to the democratization of a system (Warren 2012). Indeed, because deliberative scholars are explicitly attempting to understand the democratic potential of non-deliberative acts, adopting the nomenclature of a 'deliberative system’ would be a misnomer. Resultantly I unpack and analyze how different features deliberation, voting, contestation, and so on - contribute in different ways to democratic systems with a focus on non-electoral representation (Owen and Smith 2015). ${ }^{6}$

In this vein, Mansbridge $(2011,628)$ suggests that the study of representation should move "beyond the relationship of constituents with their elected representatives to the entire representative system". While this work is edifying, Saward $(2014,731)$ reiterates that the focus on governmental institutions remains insufficient; instead we should undertake systemic analysis at the societal level. What is needed at this stage, then, is rigorous analysis showing how democratic systems are structured across society, what positions different actors occupy, and what normative demands turn on these differences (Saward 2014). The transnational case analyzed in this article extends this societal analysis by showing how democratic systems can arise within multi-level governance arrangements.

${ }^{6}$ As such, I recognize that deliberative standards are not the only way to judge actors within a democratic system. However, because non-electoral representatives use discursive engagement to mobilize constituencies, deliberative democracy offer an appropriate toolkit to evaluate these agents at the systemic level. 


\section{Democratic Systems}

How should we conceptualize a democratic system? I focus on the three core elements: the empowered space, the public space, and transmission belts which enable deliberations and decision-making to have bidirectional impact between the spaces. ${ }^{7}$ Across the public and empowered spaces, a range of actors and institutions occupy key positions that require delineation and justification.

The empowered space is where binding collective decision-making occurs (Dryzek 2009, 1385). Empowered space is populated by legislatures, courts, political parties, cabinets, intergovernmental organizations, and so forth. Agents who have roughly equal say in collective decision-making are included here. Dryzek, Habermas, Goodin, and many other deliberative democrats suggest that when collective decisions (potentially) affect others, this activity is the domain of the empowered space. ${ }^{8}$ Diverging from this position, I contend that affectedness does not demand democratization. Rather, it is the formation of coercive rules, law, and regulations that will subject others which triggers a need for democratic legitimacy. The contrast between

${ }^{7}$ The focus on public spaces, empowered spaces, and transmission belts fits well with Habermas' (1996) two-track view of deliberative democracy.

${ }^{8}$ Although most deliberative democrats rely upon the all-affected principle to determine the boundary of the relevant demos, there is a fundamental ambivalence in the literature. In Jon Elster's $(1998,8)$ edited collection on deliberative democracy, he claims that all contributors agree that "all who will be affected by the decision" are entitled to democratic participation. Yet in the same collection, Joshua Cohen suggests that it is those "governed by" not "affected by" the exercise of power who require democratic inclusion. 
all-affected and all-subjected has been the focus of fervent debate in democratic theory (Goodin 2007). But, as Arash Abizadeh $(2012,878)$ has recently argued, "that one's interests are affected intrinsically grounds a right to due consideration, not a political right to a say in the decisionmaking process". This is because being affected does not necessarily negate self-rule and autonomy; being unilaterally subject to coercive political power, however, does undermine selfrule which stands at the core of equal authorship of democratic rule-making.

While many scholars have offered philosophical reasons underpinning the all-subjected version of democratic legitimacy, there is also a clear pragmatic reason: this criterion is required to maintain useful analytical clarity between empowered and public spaces. This is because the all-affectedness criterion collapses upon itself. In the public space citizens and other agents affect each other in myriad ways. Moreover, deliberation in the public space is supposed to affect, significantly and substantively, the decision-making of empowered space. For this reason, it is not conceptually coherent to demand that affectedness triggers democratic standing because then agents in the public space owe democratic standing to each other as well as those in the empowered space. This dissolves the boundary between empowered and public space that deliberative democrats want to maintain.

As such, I follow Abizadeh (2008; 2012) by arguing that only subjection to coercive decision-making - understood as rules, laws, regulations, and decisions that will limit the autonomy of agents in foreseeable and non-trivial ways - stands in need of democratic legitimation (see also Valentini 2011). While affectedness demands due consideration - which I take here to mean a negative duty to avoid doing harm - it does not imply the need for equal democratic standing in decision-making (Abizadeh 2012, 878). 
Next, the public space is any arena with few restrictions as to who can participate. Public space can be found in any number of democratic systems, and its scope is delimited by those subjected to the rule-making capacity of the empowered space. This space should ideally contain a wide array of actors, viewpoints, and discourses that intersect and interact. Contributions can come from citizens, activists, social movements, minipublics, internet forums, or community centers to give just a few examples (Dryzek 2009; Mansbridge and Parkinson 2012). Public spaces provide a relatively unconstrained environment for individuals and groups to coalesce, exchange arguments, and update their preferences in light of new ideas and experiences.

Finally a democratic system requires bidirectional transmission belts between empowered and public spaces. This enables reasoned deliberation in public spaces to impact and potentially shape decision-making in the empowered space. ${ }^{9}$ Reciprocally, bidirectionality allows deliberative arguments in the empowered space to inform and update the preferences and interests of audiences and constituencies. To be clear, the transmission belt is comprised of mechanisms which agents in both the public and empowered space can use, but is not a space that agents occupy per se. Such mechanisms can include campaigns, protests, lobbying, letterwriting, and media engagement. For that reason, the remainder of the article focuses on the distinction between public and empowered space. Where appropriate, though, I make note of when and how non-electoral representatives make use of transmission mechanisms, and to what effect.

${ }^{9}$ It is here that we see one of the many advantages of Saward's (2014) shape-shifting representation. This liminal conceptualization highlights how representatives present themselves in different ways to different audiences. Representatives should (be able to) shape-shift when confronted with new and better arguments. 


\section{Deliberative Capacity and the Position of Non-Electoral Representatives}

How can we judge democratic quality within and across a system? Instead of looking for a range of mechanisms that substitute for electoral mechanisms of authorization and accountability, Dryzek's (2009) notion of deliberative capacity is fruitful. ${ }^{10}$ First, deliberation demands equal inclusion. Inclusion is something of a precondition because, as Dryzek notes, without inclusion we can have deliberation but not deliberative democracy. This criterion requires that a wide array of discourses, ideas, interests, and perspectives are aired across the system and helps ensure that individuals and groups confront the views of others. Agents who hold different views should be given equal opportunity to take part in deliberation and influence outcomes. Although the inclusion of discourses and ideas are important, I focus on the inclusion of interests. Following Young $(2000,134)$, interests are what "is important to the life prospects of individuals". Interests therefore define the means for achieving self-development. ${ }^{11}$

Second, deliberation between interlocutors must be authentic, such that it is non-coercive, generalizable, and reciprocal. Agents should not use threats, intimidation, or violence to make their points. Key arguments should also be linked to more generalized claims so that individuals move beyond self-interest. Moreover, agents should attempt to put arguments in reciprocal terms acceptable to the other party (Gutmann and Thompson 1996). This ensures that agents reflect

${ }^{10}$ Although I employ Dryzek's notion of deliberative capacity, there are significant differences between his and my conceptualization and operationalization. For instance, Dryzek assesses deliberative capacity as a property of the system. I employ it as a property of parts of the system.

${ }^{11}$ Note that 'interests' can be affected or coercively limited to the extent that autonomy is constrained. In my framework, much turns on this distinction. 
upon the logical and moral foundations of their own claims by testing their convictions and arguments in ways that take seriously the position of others.

Finally, deliberation must be consequential. This means outcomes should reflect the process of deliberative preference transformation. The nature of 'outcomes' is varied; it could entail legal changes, shifts in public policy, or alterations to cultural practices (Dryzek 2009; Habermas 1996). It might also result in the creation of trust between deliberators or the formation of consensus or meta-consensus (agreement on the range of options for deliberation). These three criteria - inclusivity, authenticity, and consequentiality - can be employed to examine how democratic values are taking hold within an interconnected system.

How do the criteria of deliberative capacity vary for agents in the empowered space and in the public space? The core claim of the article is that only actors in the empowered space who can make coercive rules, laws, and decisions should be held responsible to deliberative capacity in a demanding sense. Although agents in both the empowered and the public space should not harm those they affect, they do not owe them democratic standing. I suggest that weaker standards of deliberative capacity can still be employed to judge how actors in the public space can be internally undemocratic or non-deliberative yet have good systemic effects on democratization. $^{12}$

12 This echoes Harry Eckstein's (1966) claim that it does not matter whether non-state actors are internally democratic so long as they operate within a democratic system. I deepen this insight in two ways by noting that empowered agents should be democratically responsive to all subjected actors, as well as developing criteria to evaluate how actors in the public space can fare better or worse in terms of their democratic contribution. 
The distinction between empowered and public spaces can be usefully applied for the evaluation of non-electoral representatives. In some instances, non-electoral representatives constitute part of the empowered space. We can think here about public-private partnerships, the formulation of public laws by private actors, and other situations where public actors exercise decision-making capacity that non-trivially impacts the autonomy of agents (Schäferhoff et al. 2009). This stands in contrast to non-electoral representatives in the public space. We can think here about purely advisory bodies, information-gathering agents, or organizational groups.

This division between empowered and public spaces, though evident in the literature on non-electoral representatives, has not been adequately appreciated. For instance, Montanaro (2012, 1100) argues that "individual and organizational self-appointed representatives operate mostly within civil society and the public sphere, and lack the coercive power of legislators and administrators". Montanaro implicitly recognizes that there is a division when she suggests that 'most' self-appointed representatives are in the public space. She does not go on to discuss the different normative standards of legitimacy which turn on this distinction.

Similarly Rubenstein $(2014,204)$ discusses two international groups: The Enough Project and Oxfam. Along with the International Crisis Group, John Prendergast from the Enough Project wrote Section 1502 of the Dodd-Frank Bill concerning conflict mineral provisions. These two groups also shaped the line-up of public speakers at the US Securities and Exchange Commission's 2011 roundtable discussing Dodd-Frank and S 1502. In contrast, the Oxfam case concerns the release of a report about Ghana's National Health Insurance Authority. This report was initially dismissed - though tacitly acknowledged at a later date - by the government of Ghana. These cases highlight precisely the difference between non-electoral representatives in the empowered space capable of writing rules and shaping public discussion (Enough Project) 
and the advisory nature of action in the public space (Oxfam). In her normative evaluation of these agents, Rubenstein $(2014,218)$ claims that they all exercise 'quasi-governmental' power. This, I claim, unduly tars all non-electoral agents (i.e. representatives) with the same brush when what is required is differentiation that takes account of the different parts of a system and the spaces occupied.

I trace the failure to make the distinction between empowered and public spaces to two sources: first is the treatment of non-electoral representatives as a singular class of agents; second is the mistaken notion that affectedness triggers democratic demands. To better conceptualize the actions and positioning of non-electoral representatives, I follow Saward's logic of claim-making in which a maker puts forward a subject to stand as a representative on behalf of an object. The primary goal of any non-electoral representatives is to stand for the interests of those they speak for - their constituency - and to be responsive to their changing interests over time. In doing so, their claims are directed to a range of audiences. Non-electoral representatives in the empowered space should be held to democratic standards by all those subjected to the rule-making. Non-electoral representatives in both the empowered and the public space only have a duty to avoid harming the parties they affect. On this view, if misrepresentation creates a harm to a constituency (or other affected parties), then it should be avoided. However, following the framework of systemic representation, it is only if the misrepresentation is generated by those in the empowered space that a duty of democratic consideration is prompted. ${ }^{13}$ Non-electoral representatives that operate within the empowered

${ }^{13}$ Not all forms of misrepresentation will raise to the level of harm. I recognize that there are reasonable disagreements over precisely what constitutes harm, but for my purposes any action that has a significant negative impact (without being coercive) should be viewed as harmful. I 
space thus have an additional duty: not only should they avoid harmful misrepresentation, but all their claim-making - harmful or not - should be democratically assessed at the systemic level.

Before operationalizing deliberative capacity for systemic analysis, as well as undertaking the case study, two clarifications about the respective object and source of democratic legitimacy in this framework is in order. First, on my account non-electoral representatives should be judged by their role in the system, with democratic consideration owed to actors subjected to coercive rules. This framework narrows down the range of agents we can turn democratic demands against to only those in the empowered space. While this may seem to let a lot of powerful figures off the democratic hook, it also sharpens our understanding of who has democratic obligations and to whom. It therefore remains a worthwhile distinction to draw even if intensive empirical analysis is required to determine which non-electoral representatives are in the empowered space.

Second, it may be objected that non-electoral representatives only have a democratic duty toward those they claim to speak for - their constituency. Saward (2010), for instance, maintains that non-electoral representatives should be democratically legitimated by the 'appropriate constituency': those agents for whom a non-electoral representatives claims to speak as well as those who identify with the claim itself. I have maintained that the primary goal of non-electoral representatives should be to stand for the interests of their constituency, and to be responsive to their changing interests over time. But because non-electoral representatives are implicated in shaping, defining, organizing, and mobilizing these interests, democratic analysis needs to be systemic, not limited to the representative-constituency relationship.

thank an anonymous reviewer for bringing the notion of misrepresentation to my attention and pressing me to clarify my position. 
In other words, the complications engendered by potential framing and manipulation of constituencies through non-electoral claim-making suggests that we should not solely judge the democratic legitimacy of a non-electoral representative by reference to their own constituency. Rather, it is the arguments and interests advanced by non-electoral representatives that should be scrutinized across the system, trialing the claims of subjected parties against one-another (Disch 2011). The ways in which non-electoral representatives are responding to, or are themselves altering, the interests of their constituency should also be exposed to system-wide deliberative argumentation. The framework offered here provides a set of normative standards to judge the quality of argument at a systemic level, which in turn provides a safeguard against manipulation of constituencies by non-electoral representatives. 
Table 1: Non-Electoral Representatives and Deliberative Democratic Legitimacy

\begin{tabular}{|c|c|c|}
\hline $\begin{array}{l}\text { Deliberative } \\
\text { Capacity }\end{array}$ & $\begin{array}{l}\text { Democratic Task of the Non-Electoral Representative: } \\
\text { Empowered Space }\end{array}$ & $\begin{array}{l}\text { Democratic Task of the Non-Electoral Representative: } \\
\text { Public Space }\end{array}$ \\
\hline Inclusivity & $\begin{array}{l}\text { A duty to include the changing interests of their } \\
\text { constituency in the empowered space } \\
\text { - A duty not to exclude the interests of other } \\
\text { subjected actors from the empowered space }\end{array}$ & $\begin{array}{l}\text { A duty to promote the changing interests of their } \\
\text { constituency across the public space and to seek } \\
\text { recognition of these interests within the empowered } \\
\text { space } \\
\text { Promotion of their constituency can entail seeking to } \\
\text { exclude others who are over-represented }\end{array}$ \\
\hline Authenticity & $\begin{array}{l}\text { Must not use coercion to change the interests of } \\
\text { actors in the empowered or public space } \\
\text { - Must make (publicly) generalizable claims that } \\
\text { connect their position with the interests of subjected } \\
\text { and affected parties }\end{array}$ & $\begin{array}{l}\text { - Coercion against other affected parties is } \\
\text { unacceptable, however bargaining and self-interest is } \\
\text { acceptable if it promotes their constituents' interests } \\
\text { - No duty to make generalizable claims - arguments } \\
\text { based on self-interest can be made, but } \\
\text { representatives must listen to other affected groups }\end{array}$ \\
\hline
\end{tabular}




\begin{tabular}{|c|c|c|}
\hline & $\begin{array}{l}\text { - Must frame arguments in ways acceptable to other } \\
\text { subjected parties }\end{array}$ & - Partisanship and enclave deliberation is valid \\
\hline Consequentiality & $\begin{array}{l}\text { - Must generate laws, regulations, rules, and } \\
\text { decisions that reflect inclusion and authenticity } \\
\text { - A duty to be open to changing interests, } \\
\text { preferences, and culture within the empowered } \\
\text { space }\end{array}$ & $\begin{array}{l}\text { - Can generate consequences through contestation, } \\
\text { protest, and so on } \\
\text { - No duty to change preferences or interests }\end{array}$ \\
\hline
\end{tabular}


The standards for those in the empowered space are demanding. They reflect how nonelectoral representatives can be considered democratic without electoral mechanisms. Including the (changing) interests of those for whom they speak should remain the primary goal of nonelectoral representatives. Questions about how constituencies are being invoked and mobilized as well as how constituencies react to those claims made on behalf of their interests - are subjected to inclusive deliberative contestation. The duty not to exclude the interests of other subjected parties helps foster a range of important viewpoints and respects the basic equality of others' interests.

The authenticity condition makes deliberation within the empowered space susceptible to better arguments and ensures that one set of interests are trialed against competing ideas and interests. The requirement against coercion ensures that decision-making is grounded in argumentation while threats recede into the background (Habermas 1996). Generalizable claims help provide democratic justification from rule-makers to both subjected and affected parties, while reciprocity specifically connects claim-making with the position of other subjected actors. Finally consequentiality ensures that those agents who take a privileged and empowered decision-making position work toward creating rules that have been deliberatively-tested, while remaining open to changing the culture and structure of the empowered space itself.

The table also outlines how non-electoral representatives in the public space can speak on behalf of their constituency in ways that are not strictly deliberative yet still promote democratization. Excluding others, bargaining, self-interest, partisanship, and contestation are all antithetical to deliberation in a conventional sense. Because the systemic phase specifically probes how non-deliberative acts can promote democratization in other ways, we require reasonably clear principles to assess which non-deliberative acts are acceptable and how they 
might promote democratization in order to stop the systemic phase from reifying nondeliberative acts or finding post hoc ways of justifying all anti-deliberative actions. The criteria outlined above provide these standards.

For instance, the exclusion of over-represented groups might be democratically necessary (Dovi 2009). Thinking of how actors in the public space can push for this outcome is important. Moreover, forms of constrained self-interest and bargaining - that are not coercive - can help promote the interests of disenfranchised groups. ${ }^{14}$ Partisanship and enclave deliberation can also help actors formulate their ideas with like-minded individuals and provide a united front to 'poke holes' in weak arguments (White and Ypi 2011). This is especially important for historicallydisadvantaged groups. Finally contestation and protests from the public space are often necessary to revitalize the actors and interests within empowered spaces and generate systemic reflexivity (Disch 2011; Parkinson and Mansbridge 2012). All considered, then, non-deliberative acts are acceptable if they supplement deliberative quality across other parts of the system, directly remedy democratic deficiencies in the empowered space, and/or enhance systemic reflexivity when non-democratic norms become entrenched.

Note that, unlike several recent deliberative theorists (Parkinson and Mansbridge 2012), I resist the urge to specify or elucidate how actors in the empowered space might make use of nondeliberative acts to enhance democratization. Although there may be some instances where this is possible, it should be avoided precisely because it is those who are subjected to coercive rulemaking in the public space who should determine the composition of arguments considered

${ }^{14}$ The actions cannot be coercive for two reasons. First, this would violate the condition of nonharm of affected groups. Second, coercive power is the privy of the empowered space, and thus would require democratic legitimation. 
within the democratic system (Dryzek 1996). For non-electoral representatives in both the empowered and public spaces, there remains a duty to avoid harming the fundamental rights and interests of affected parties (Abizadeh 2012; see also Rubenstein 2014). This also puts limits on the scope of acceptable non-deliberative acts in the public space. This table provides a framework to think about when non-electoral representatives trigger demands of democratic deliberation and to assess their democratic quality within a system.

\section{NON-ELECTORAL REPRESENTATION IN CONTEXT: THE COLLAPSE OF ACTA}

To illustrate and assess the different spaces occupied by non-electoral representatives within a democratic system, I undertake a case study of the Anti-Counterfeiting Trade Agreement negotiations. I describe the scheme of institutions and actors that took part in deliberations and make distinctions between the empowered and public spaces. The case shows how democratic systems arise in a world where sub-national, national, and transnational bodies have profound impact on one-another in ways that require sustained treatment across formal and informal sites. It explicitly highlights how coercive power beyond the state can trigger demands for democratization and the way the nature of constituencies and the demos are altered by claimmaking. This helps demonstrate how a democratic systems approach can make sense of complex situations while using deliberative capacity to unpack the democratic legitimacy of different nonelectoral representatives.

ACTA was a plurilateral agreement designed to raise the standards of IP law in 38 participant countries, namely the US, EU member states, Australia, Canada, Japan, Mexico, 
Morocco, New Zealand, Singapore, South Korea, and Switzerland. The basic idea underpinning ACTA was to ratchet up domestic and international law against copyright infringement, counterfeiting, and digital rights circumvention. ACTA negotiations took place outside of the World Trade Organization (WTO) and the World Intellectual Property Organization and explicitly sought to go beyond the Agreement on Trade-Related Aspects of Intellectual Property Rights (TRIPS) that was adopted by the WTO in 1995. TRIPS successfully linked trade with intellectual property so that states which failed to uphold strict laws for IP governance would face trade sanctions through the WTO system. Although TRIPS was largely seen as an IPmaximalist policy, many states have endeavored over the past two decades to continue raising IP law across the globe. This has been spearheaded by the US, EU, and Japan. The US in particular has attempted to use bilateral and multilateral trade deals to induce TRIPS-plus standards in different countries (Sell 2013). ACTA follows the pattern of linking trade to intellectual property as a means of generating compliance and sanctions.

Although the specific concept for ACTA arose in 2005, negotiations began in earnest in 2007 with the announcement of a formal treaty coming from the US, Japan, Switzerland, and the EU. From 2007 until late 2010 nine rounds of ACTA negotiations took place under much secrecy. Indeed, both the content and location of negotiations were concealed. During that time, however, several drafts of the text were published by WikiLeaks. From leaked drafts and subsequent official releases, it is clear that ACTA demanded significant domestic and transnational legal alterations. To give a brief summary, ACTA would have: enabled law enforcement authorities to act ex officio for search and seizures; exposed to stronger criminal penalties companies that benefit from pirated products; given internet service providers (ISPs) the ability to extra-judicially cut consumers from internet access if suspected of illegal 
downloading; further criminalized the circumvention of digital rights management; and, created new obligations for the seizure and destruction of suspected counterfeit goods. ${ }^{15}$ ACTA also provided a 'damages remedy' so that rights-holders could estimate losses from counterfeit or copyright breaches that national judges would consider, and required the establishment of a standing committee composed of at least one member of each participant country. This committee would have been responsible for reviewing the implementation of ACTA, considering amendments to ACTA text, and convening working groups that would seek advice of rightsholders. ${ }^{16}$ The creation of these coercive rules under ACTA would have bound governments and individuals in non-trivial ways, and thus stood in need of democratic legitimation.

ACTA negotiations concluded in late 2010 and opened for signatures in early 2011. Over the next 18 months almost every participating country signed the treaty. However, despite the secrecy and momentum, ACTA collapsed in 2012. This result came after much public and governmental backlash. This began as unrest in 2010 when the Mexican Senate voted to withdraw from the agreement after an anti-ACTA Twitter campaign and continued as EU member-nations and Members of the European Parliament (MEPs) pushed back against some of the most onerous provisions. This was coupled with widespread citizen discontent. Throughout early 2012 numerous citizen groups gathered against ACTA culminating in myriad highvisibility protests. Eventually the EU Parliament voted decisively against ACTA which combined with rejection by other countries - unofficially ended the possibility of a ratified treaty

${ }^{15}$ See “ACTA: USTR's talking points to WTO Council for TRIPS”. Available at: http://keionline.org/node/1008 (accessed May 12, 2015).

${ }^{16}$ ACTA draft December 2010, available from http://trade.ec.europa.eu/doclib/docs/2010/april/tradoc_146029.pdf (accessed May 14, 2015). 
(Dür and Mateo 2014). The promotion of ACTA, and its surprising defeat in 2012, was shaped by many non-electoral representatives in both the empowered and public space that warrant analysis of this case. ${ }^{17}$

\section{Empowered Space}

The empowered space of ACTA composed many different actors such as governments, national sub-committees, trade agencies, and bureaucrats that cut across national and international lines. The most prominent national body was the US Trade Representative (USTR) and the IP division headed by Stan McCoy. The USTR has been central to the negotiation of many international IP agreements such as the Caribbean Basin Initiative, TRIPS, and the current Trans-Pacific Partnership (TPP). The USTR is responsible for creating trade policy and making recommendations to the US President. The USTR also organizes bilateral and multilateral trade negotiations, maintains a permanent role in the National Economic Council, and releases the

${ }^{17}$ To ensure that non-state actors in the ACTA process were making representative claims, I drew a sample of 40 actors from a data set of non-state actors in ACTA by Dür and Mateo (2014) and combined this with the set of 10 I identified in the empowered space (see below). I stratified the sample to contain bodies from most participating ACTA countries. I completed a textual analysis of the webpages, constitutional documents, and mission statements of these nonstate actors. Of the 50 actors, 32 made explicit representative claims, while a further 15 made implicit claims (by employing terms such as 'leadership', 'stewardship', or 'voice' on behalf of others). Only three (3) made no recognizable representative claim. See attached appendices. Further details on file with author. 
annual 'Special 301 Report' that details the IP-status of countries around the globe. Special 301 was introduced in 1988 to complement Section 301 of the 1974 Trade Act which authorizes the President to take all necessary action against states which violate trade standards. Special 301 essentially 'names and shames' countries that are failing to live up to international IP standards by listing 'Priority Foreign Countries', a 'Priority Watch List', and a 'Watch List'. Being listed as a priority target is the first step toward a Special 301 investigation and then WTO (or bilateral) retaliation from the US. Beyond the domestic realm, regional bodies (mostly from the EU) and international groups (such as formal IOs) were involved in the ACTA process.

ACTA exemplifies the importance of non-electoral representatives in multilateral trade and IP affairs. From different parts of the world, hundreds of non-state actors - interest groups, business lobbies, NGOs, and individuals - were engaged in the ACTA process. From the empowered space, I identified 10 key actors including the Software Alliance (BSA), the International Intellectual Property Alliance (IIPA), the Motion Picture Association of America (MPAA), Pharmaceutical Research and Manufacturers of America (PhRMA), and the Recording Industry Association of America (RIAA) ${ }^{18}$ Almost without exception, these agents made representative claims and, although predominantly based in the US, have regional presence across Oceania, the EU, and Asia. These groups all supported the formation of ACTA and demanded stronger IP provisions to protect their market share.

${ }^{18}$ I counted these groups because they were included in the leaked WikiLeaks and KEI drafts from internal ACTA meetings. Although some bodies are subsidiary members of each other, I counted them separately. See "KEI: White House shares the ACTA Internet text with 42 Washington insiders", available at: http://keionline.org/node/660 (accessed May 11, 2015). See appendix B for full list. 
Some might object that lobbyists and membership-based industry groups defy the constructivist model I have attached to non-electoral representatives. Instead they might be better considered in principal-agent terms, with the principals (member organizations) delegating specific mandates to the agent (lobbyists, leaders of membership groups). While there is certainly a principal-agent dynamic at play, two reasons contribute to the depiction of industry groups and lobbyists as non-electoral representatives in constructivist terms. First, industry groups often have internal battles about how collective interests should be generated and portrayed. Several of the groups noted have excluded members for being too slow or polarizing in their decision-making procedures. As such, lobbyists and leaders of membership groups still have to find ways of (re-)presenting the variegated interests of their principals during meetings, press conferences, and other moments of representation. Second, and perhaps more saliently, viewing lobby and industry groups as a collective also highlights how these bodies make representational claims on behalf of other constituencies outside of the formal organizational membership. ${ }^{19}$ The ways, then, that lobbyists and membership groups generate collective

${ }^{19}$ See attached appendices for more information on the representational claims invoked by these groups. To give just one specific example, in an official press release from January 2015, the MPAA celebrated the installment of Stan McCoy as their Senior Vice President and Regional Policy Director. In doing so, the MPAA notes that McCoy's experience is critically important for curbing copyright piracy, "not just to our member studios, but to the seven million people who work in the creative sector throughout the EU." See "MPAA Announces New EMEA And Global Leads". Available at: http://www.mpaa.org/wp-content/uploads/2015/01/MPAAAnnounces-New-EMEA-and-Global-Leads.pdf (accessed July 27, 2015). 
interests and mobilize constituencies beyond formal delegation chains provide reasons to asses these agents through a constructivist lens as non-electoral claim-makers. ${ }^{20}$

Although these non-electoral representatives were all linked with ACTA negotiations, more needs to be said concerning whether they were really part of the empowered space. Admittedly, delineating who has roughly equal say in the formation of coercive rules is a difficult prospect. There were two main reasons for including these non-electoral representatives, though. First, these industry bodies all run a 'revolving door' policy with the USTR and other national trade groups. For instance, subsequent to ACTA, the MPAA has hired Stan McCoy while the BSA has hired Victoria Espinel (previously the US IP Enforcement Coordinator in the White House). This is seen as quid pro quo so that industry positions are reflected in governmental policy. ${ }^{21}$ Second, and more directly, the Special 301 Report is "a public law devoted to the service of private corporate interests" (Drahos and Braithwaite 2002, 89). Special 301 is employed by major industry lobbyists to push change in domestic laws around the world through the watch list function. This is supplemented by the 'out-of-cycle' review function of notorious markets, in which the USTR identifies and pressures foreign governments to increase IP regulation.

${ }^{20}$ I thank an anonymous reviewer for encouraging me to specify how lobbyist and industry groups - which employ a principal-agent model - fit the constructivist characterization undergirding this article.

${ }^{21}$ See "Techdirt: Revolving Door". Available at: https://www.techdirt.com/articles/20140422/06011926988/revolving-door-mpaa-hires-chief-ustrnegotiator-behind-acta-tpps-ip-chapter.shtml (accessed May 20, 2015). 
For these reasons, several non-electoral representatives have become part of the empowered space in IP governance generally. As Drahos and Braithwaite $(2002,96)$ have rightly noted, interest groups and the USTR have become increasingly intertwined, not just in terms of contact and information-exchange, but also by "plugging each other into the politics of their respective decision-making processes, working out which countries they were going to hit and which to leave alone for the time being." This occurred specifically in ACTA negotiations where the BSA, IIPA, MPAA, PhRMA, and the RIAA all explicitly pushed for the treaty. ${ }^{22}$ These bodies did not just lobby for their preferred provisions or provide information for other decisionmakers, but rather dictated precise policy to the USTR. ${ }^{23}$ ACTA would also have given industry groups (such as ISPs) the legal right to make and enforce rules on illegal downloading, thus cementing their place in the empowered space. ${ }^{24}$ Because ACTA - through search and seizure, confiscation and destruction of goods, termination of internet accounts, and other changes to domestic and international law - would have coerced individuals in non-trivial ways, the nonelectoral representatives that take part in the formation of rules required democratic legitimation.

${ }^{22}$ See the "IIPA Applauds the Formal Signing of ACTA in Tokyo, Japan." Available at: http://www.iipa.com/pressreleases/2011_Sep30_IIPA_ACTA_Press_Release.PDF (accessed April 30, 2015).

${ }^{23}$ Because lobbying may be purely advisory, the difference between empowered and public space does not match the dichotomy of inside and outside lobbying in the literature on interest group politics (Dür and Mateo 2014).

${ }^{24}$ For instance, Time Warner is an ISP in the US and part of the MPAA. 


\section{Public Space}

Many actors also fill the public space of ACTA. Most salient are the domestic publics from the negotiating states and individuals in other states who would also be subjected to ACTA regulations (tourists, importer/exporters, workers in the supply chains, and so on). Again, though, many non-electoral representatives - such as transnational NGOs and industry groups with advisory capacity - also compose the public space. Although a full listing is not possible here, I documented and coded 40 actors in the public space across the EU, US, Asia, and Australia. ${ }^{25}$ This included groups such as Avaaz, Consumers International, Content Creators Coalition (CCC), the Electronic Frontier Foundation, La Quadrature du Net, Oxfam, Public Knowledge, and many others. Of 40 groups, 38 engaged in claim-making for specific constituencies, such as 'citizens of France', 'residents of North Rhine-Westphalia', 'internet users', 'consumers', 'future generations', and 'the global poor'. This indicates that fluid constituencies, which deviate from national electorates, were mobilized throughout the ACTA process. Whereas non-electoral representatives in the empowered space all sought stronger IP regulations, the public space contained a wide array of actors and interests (both for and against ACTA).

Actors in the public space were certainly visible throughout the ACTA negotiation process. The lack of transparency from participating countries was first noted by NGOs such as Knowledge Ecology International (KEI) that unsuccessfully filed freedom of information (FOI) requests with the US Government for drafts of the ACTA text (Levine 2011). This was followed up by individuals and citizen groups mobilizing against the secrecy of ACTA and the lack of access to drafts. Many non-electoral representatives were instrumental in disseminating

${ }^{25}$ See appendix A for the full list. 
information across the public space, lobbying elected representatives, and organizing protests. As such, non-electoral representatives in the public space employed transmission mechanisms to connect publics with the empowered space.

This basic schematic helps to capture the key elements of this democratic system. The remainder of the article outlines how non-electoral representatives in the empowered space (who owe democratic standing to subjected groups) failed in their duty, whereas those in the public space employed deliberative and non-deliberative means to enhance systemic reflexivity and bring about the collapse of ACTA in ways that amounted to a more democratic system.

\section{DELIBERATIVE CAPACITY ACROSS THE DEMOCRATIC SYSTEM}

\section{Inclusivity}

The empowered space of ACTA negotiations was highly exclusive and unequal, both in terms of the number of participants and the range of interests. Specifically, the formal treaty process was dominated by a narrow focus on IP-maximalism. Given that ACTA was designed to strengthen IP law in signatory states, this is perhaps unsurprising. The logic of IP-maximalism is fairly straightforward: stronger IP standards provide an incentive for creators to innovate. This requires a system that gives creators a temporary monopoly over their invention as well as punishes actors who violate IP laws through counterfeit, copyright breaches, and reverse engineering. Since the 1980s, IP has been linked with free trade - legally and culturally - as a way to secure legal compliance (by sanctioning derogating agents) and provide global reach. The logic of IP- 
maximalism has come to dominate many industries (especially technology and pharmaceuticals) and trade departments across the world (Sell 2013).

ACTA explicitly sought more IP regulation and stronger punishments for states, corporations, and individuals who break transnational rules. Non-electoral representatives from industry groups were especially forceful in pushing this IP-maximal line. In 2009 Dan Glickman, then-CEO of the MPAA, asked for a 'sound and comprehensive' ACTA treaty (Levine 2011). This correspondence depicts the exclusionary tendency of empowered non-electoral representatives when Glickman suggests that concerns over the secretive nature of ACTA were a 'distraction', and that the general public should be excluded because they are "indifferent to [the film industry's] situation, or actively hostile toward efforts to improve copyright enforcement worldwide. ${ }^{26}$ This interest in exclusion was largely accepted by governments and bureaucrats. Throughout the remainder of ACTA, then, draft texts, meeting dates, and roundtable locations were deliberately obscured from public view augmenting the exclusionary nature of negotiations. While these non-electoral representatives may be including their constituents' interests in the empowered space, the active effort to block other subjected parties violates standards of inclusive democracy.

During ACTA, empowered non-electoral representatives also sought to increase their political presence by holding a series of 'off the books' negotiations and meetings with Canadian and US government officials. These negotiations took place in Canada to bypass US laws concerning lobbying. This information was only attained after the negotiations when the chief MPAA negotiator - former US Senator Christopher Dodd - was found to have kept his name off

26 “Glickman letter". Available at: http://www.scribd.com/doc/22785108/MPAA-letter-re-ACTA (accessed May 19, 2015). 
all official documents. ${ }^{27}$ It should also be noted that empowered agents - from the IIPA, MPAA, RIAA, and PhRMA - tend to exclude actors from their own organizations that offer dissenting opinions and interests to IP-maximalism. For instance, the IIPA - a coalition of six bodies which represents more than 3,200 firms - has often kicked out groups that are too slow in making decisions (Drahos and Braithwaite 2002, 92). This kind of action makes the organizations internally homogenous and again decreases the range of interests in the empowered space.

Ironically, the attempts at procedural exclusion during ACTA backfired on the nonelectoral representatives in the empowered space. The barring of alternate viewpoints and rejection by the USTR of FOI requests actually drew public attention to the lack of transparency of ACTA, notoriety which WikiLeaks fueled by diffusing draft texts. Non-electoral representatives in the public space were quick to jump on the non-transparent and unaccountable nature of ACTA by demanding inclusion of their interests. In 2010 and 2011 KEI and Public Knowledge in the US attempted to politicize the exclusion of public interest in ACTA and wrote to US Senators (such as Ron Wyden, who eventually came out against ACTA) to highlight how consumers would be hurt by ACTA provisions. ${ }^{28}$ This tactic had some success and was followed by online mobilization of different constituencies through a variety of websites. Users of these sites wrote to their elected representatives demanding more information about ACTA and rejection of the treaty.

27 “The MPAA's Secret Lobby Campaign on Bill C-11 and a Canadian SOPA”. Available at: http://www.michaelgeist.ca/content/view/6542/125/ (accessed May 3, 2015).

28 “Senator Wyden Issues Statement on ACTA”. Available at: http://keionline.org/node/832 (accessed March 21, 2015). 
This strategy gathered pace and continued across the EU: Non-elected representatives in the public space sought to include the interests of citizens, internet users, consumers, and other subjected and affected parties in the ACTA process. Although these groups used nondeliberative tactics - such as protests and contestation - they were successful in helping to bring ACTA undone within Europe. The public space thus helped counterbalance the exclusionary demands made by non-electoral representatives in the empowered space who had sought secretive negotiations and fostered the marginalization of many subjected groups.

\section{Authenticity}

The secrecy of ACTA negotiations makes it difficult to judge the authenticity of debate. However, building upon the previous section, we can begin to comprehend how non-electoral representatives in the empowered space violated core tenets of deliberative democracy throughout ACTA. In terms of coercion, many of the empowered non-electoral representatives used pressure and threats against government agencies in the empowered space. For instance, the IIPA leaned on the USTR to list other ACTA negotiating states (namely Mexico, Canada, and several EU countries) on the 'priority watch list' and 'watch list' for the 2010 Special $301 .{ }^{29}$ The USTR followed almost all recommendations and accepted, as they do every year, industry group estimates for trade losses due to piracy and counterfeit. ${ }^{30}$ As such, ACTA negotiations took place

${ }^{29}$ See "IIPA Letter to Stan McCoy for 2010 Special 301". Available at: http://www.iipa.com/pdf/2010SPEC301COVERLETTER.pdf (accessed April 4, 2015).

${ }^{30}$ This ability to report losses, which have legal binding, cements these industry groups in the empowered space. 
in the shadow of coercion as the USTR and industry groups used market size and the Special 301 process (linked to trade sanctions) to push their own interests. This coercive backdrop fostered by actors in the empowered space undermined the deliberative democratic process of multilateral negotiations. Threats and sanctions were also directed at subjected groups in the public space (such as WikiLeaks and KEI) by empowered non-electoral representatives, which compounded the exclusionary hue of ACTA negotiations.

In contrast, non-electoral representatives in the public space contested the coercive elements behind ACTA. Public interest groups hit back against the secrecy of ACTA, and stressed the importance of fundamental rights over free trade. Although these groups engaged in protests and other forms of contestation, such actions helped to counteract the exclusive and coercive nature of the empowered space. This enabled actors in the public space to speak for their constituencies in forceful ways. Because these agents do not owe democratic standing to affected or subjected parties, they have a wider-range of acceptable options which can be employed to make their point.

Empowered non-electoral representatives did make some generalizable arguments during ACTA meetings and negotiations. The logic of IP-maximalism suggests that strong IP rules generate creativity and jobs which benefit everyone. This argument was made during ACTA when empowered non-electoral representatives suggested that removing counterfeit goods from the global market would serve the wider public good. For instance, PhRMA and the International AntiCounterfeiting Coalition (IACC) claimed that "illegal medicine has not been subjected to 
appropriate research trials" and causes a reduction in state revenue through lost taxes. ${ }^{31}$ As such, health and welfare is at stake when IP rules are broken.

Non-electoral representatives in the public space did note that these generalizable claims have merit; however they argued that the costs and dangers of counterfeit goods were incorrectly calculated by rights-holders in the empowered space. The Foundation for a Free Information Infrastructure and KEI, to give just two examples, both argued that financial losses due to counterfeit are wildly over-estimated by rights-holders and uncritically accepted by governments. ${ }^{32}$ Moreover, the methodology employed by rights-holders is often under-specified, and the lack of dialogue between non-electoral representatives in the empowered space and the public space mean that the figures are rarely double-checked. Although some generalizable arguments were made by empowered non-electoral representatives during ACTA, public agents were quick to point out that these claims needed verification to show how, and to what extent, public interests were really at stake.

In terms of the final criterion - reciprocity - empowered non-electoral representatives fared poorly. The MPAA and the RIAA made few public statements about ACTA, and their position went well beyond what many other industry representatives (in the public space) and states wanted. ${ }^{33}$ Moreover, their arguments did not address how ACTA would impact those

31 "IACC statistics". Available at: http://www.iacc.org/counterfeiting-statistics.html (accessed April 5, 2015).

32 "FFII on ACTA". Available at: http://acta.ffii.org/?p=1488 (accessed May 12, 2015).

33 “MPAA/RIAA lose big as US backs copyright limitations.” Available at: http://arstechnica.com/tech-policy/2012/07/op-ed-eus-rejection-of-acta-subtly-changed-trade- 
subjected to the new laws. This requires more than general arguments grounded in the common good or public reason, but rather requires reciprocal points about how ACTA would impact citizens of signatory states, internet users, those who need access to essential medicine, and tourists worried about data privacy (to name just a few subjected groups). These types of arguments did not emanate from the empowered space. This is not surprising because governments also did not make much effort to include views from the public space. As conceded in a 2012 ACTA report, Stan McCoy stated that "there is no independent verification of these industry reports and there were no tough questions for industry regarding their testimony". ${ }^{34}$ As a result, non-electoral representatives and governments failed to couch their arguments in terms acceptable to those subjected to the rules. Because agents in the empowered space have a democratic duty to test their arguments against the viewpoints and interests of other subjected actors, this is democratically problematic.

Over time, however, non-electoral representatives in the public space found alternate ways to have their interests considered. Myriad non-electoral representatives took it upon themselves to decry the secretive nature of ACTA, expose inconsistencies in pro-ACTA arguments, and organize constituencies for public protests and other actions. Avaaz in the EU, for instance, collected nearly three million signatures in an online petition against ACTA. La Quadrature du Net, in combination with Oxfam, were instrumental in confronting EU law-landscape/ (accessed May 12, 2015). This was one of the main reasons that the EU, after being a proponent of ACTA for several years, began to shy away from the agreement. 34 “Techdirt: Revolving Door.” Available at: https://www.techdirt.com/articles/20140422/06011926988/revolving-door-mpaa-hires-chief-ustrnegotiator-behind-acta-tpps-ip-chapter.shtml (accessed April 23, 2015). 
parliamentarians and organizing protests. ${ }^{35}$ Starting in Poland in early 2012 and moving on to Slovenia, Sweden, the UK and many other locations, hundreds of thousands of citizens mobilized against ACTA. As an example, on February 11 2012, 58 protests involving around 100,000 people took place within Germany alone, as citizens sought government recognition of their interests and ideas (Dür and Mateo 2014). This highlights how public non-electoral representatives managed to generate interest and mobilize constituencies on rapidly-evolving terrain. Empowered non-electoral representatives such as the IIPA and International Federation of the Phonographic Industry (IFPI) responded to these protests by claiming that ACTA states should not take into consideration the views of Avaaz and other non-electoral representatives because these anti-ACTA petitions and protests 'undermined the democratic process' of multilateral negotiations. ${ }^{36}$

Public non-electoral representatives (such as STOPP ACTA and La Quadrature) did not accept being ostracized and, as well as engaging in contestation, also mounted new and successful arguments against ACTA. One prominent example was the claim that elected EU representatives (especially MEPs) should not be sidelined during the construction of ACTA texts. MEPs became increasingly dissatisfied with their isolation and eventually voted decisively against the treaty. Indeed this was the first exercise of veto power by the EU Parliament since the

35 “La Quadrature du Net.” Available at: http://www.laquadrature.net/fr/ACTA (accessed April $23,2015)$.

36 “IFPI \& Other Lobbyists Tell Parliament That ACTA Protests Silence The Democratic Process.” Available at: https://www.techdirt.com/articles/20120215/04435217767/ifpi-otherlobbyists-tell-parliament-that-acta-protests-silence-democratic-process.shtml (accessed April 9, 2015). 
2010 introduction of the Treaty on the Functioning of the EU. The fact that the EU Parliament (which voted 478 to 35 against ACTA) and many national parliamentarians had initially supported ACTA, but slowly turned against it, highlights two pertinent factors: first, nonelectoral representatives in the public space were successful in mobilizing other citizens and launching reciprocal arguments against the exclusion of their elected representatives; and second, argumentation and public pressure led to transformation within the empowered space. Although empowered non-electoral representatives did not shift their interests, some government actors did reject ACTA following in the wake of actions and reactions by public non-electoral representatives.

\section{Consequentiality}

Consequentiality entails that outcomes should follow from inclusive and authentic deliberation. Outcomes, to reiterate, can refer to formal legal changes, informal norm alterations, and anything in between. The case of ACTA is particularly illuminating on this score. Empowered nonelectoral representatives and government officials seeking to construct ACTA excluded the (rival) interests of subjected groups and engaged in coercive and non-reciprocal deliberation. A typical motive for having secretive and minilateral negotiations is to ensure fast agreement on complex topics. While this tactic has been used successfully in the past (for IP negotiations and other agreements in international relations), it failed for ACTA. Indeed, attempts by empowered actors to shield documents, information, and meetings from public viewing led to increased interest in the process. ACTA became more politicized as time went on, and negotiations clearly failed as subjected groups such as states, non-state actors, and individuals rejected the treaty. 
Moreover, it seems clear that the preferences and interests of most actors in the empowered space did not change over time. Although the Mexican Senate and many MEPs changed their position, most non-electoral representatives did not. After ACTA failed, these groups - the IIPA, MPAA, RIAA, PhRMA, and others - have turned toward the TPP as a way to secure global IP-maximalism. ${ }^{37}$ Similarities between ACTA and the TPP abound: the TPP involves most of the same nation-states as ACTA (although the EU is notably absent, perhaps recapitulating the notion that MEPs have changed their views and interests); the TPP seeks to raise domestic and international legal standards in terms of IP; and the TPP has been secretive and exclusive. As with ACTA, TPP secrecy has piqued public interest and draft documents have been leaked. ${ }^{38}$ The fact that many of the empowered non-electoral representatives from ACTA have turned toward the ongoing TPP suggests that these actors have not altered their preferences in response to arguments and contestation from public groups. Although they speak on behalf of a certain set of interests from their constituency, agents in the empowered space must be open to changing their opinions vis-à-vis the force of argumentation from other subjected groups: a democratic duty that has certainly not been met.

In contrast, actors in the public space were much more successful in generating consequential outcomes. Although the defeat of ACTA was the primary goal of many public non-electoral representatives who stood against IP-maximalism, these groups had many subsidiary aims: to expose secretive negotiations, organize protests, gather signatures, and foster

${ }^{37}$ There are also many similarities with The Transatlantic Trade and Investment Partnership. 38 “KEI analysis of Wikileaks leak of TPP IPR text.” Available at: http://keionline.org/node/1825 (accessed May 1, 2015). 
public interest in the technical field of IP regulation. These outcomes were largely reached. Moreover, mobilizing constituencies on such a technical topic shows why political representation should be viewed both constitutively - as constituencies were brought into being through claimmaking - and systemically - as public non-electoral representatives addressed and clashed with elected leaders across the US, the EU, many other empowered sites.

Although non-electoral representatives in the public space were not always acting deliberatively through the use of protests, self-interested arguments, and forming partisan coalitions, they do not subject others to coercive rules and thus do not require democratic legitimation. These agents have a duty to speak for their constituency - concerned citizens, internet users, medical professionals, and so on - but must only avoid harming affected parties. By seeking to combine arguments with contestation (but not resorting to outright coercion against affected parties), public non-electoral representatives upheld this standard. Overall, public actors managed to counteract the undemocratic nature of the empowered space which led to a more vibrant and reflexive democratic system that put the interests of subjected and affected parties at the core.

\section{CONCLUSION}

In conclusion, I make three points. First, non-electoral representatives occupy key positions in today's globalizing world. Some of these actors take part in the formulation of coercivelybinding rules located in the empowered space, whereas others operate in the public space providing information, coalescing interests, or opposing sites of public power. The theoretical literature on non-electoral representatives should disentangle the different democratic demands 
which follow from empirical variance. Employing deliberative capacity as the indicator of democracy, I have elucidated a systemic framework against which non-electoral representatives in the both empowered and public spaces can be judged.

Second, I have applied this framework to the case of ACTA negotiations. I outlined how state governments, IOs, bureaucrats, EU parliamentarians, and non-electoral representatives (mostly industry groups) occupied the empowered space and sought to forge new and coercive IP laws within and beyond signatory states thus showing how transnational bodies can exercise coercive forms of power that trigger democratic demands (Abizadeh 2012). This was contrasted against the public space, composed of individuals and non-electoral representatives, that also cut across national boundaries. Although empowered non-electoral representatives managed to press their views throughout ACTA, they did so in ways that were exclusive of alternate interests and were non-authentic. Public non-electoral representatives countered these undemocratic negotiations through a combination of argument and contestation. Given that ACTA was eventually rejected, empowered agents did not manage to generate consequential outcomes whereas public actors were influential in launching arguments, mobilizing new constituencies, and changing preferences. Thus, the actions manifest in the public space offset undemocratic interactions in the empowered space and contributed to a reflexive and democratic system.

Finally, the theoretical amalgamation of democratic systems with the constructivist turn in political representation helps uncover the promises and pitfalls of each nascent approach. On one hand, deliberative democrats need to be more attuned to how systems are structured, which positions actors occupy, and what normative standards turn on these distinctions. Much hinges, so I have argued, on the difference between acting in empowered and public spaces and, in turn, whether these spaces should be defined in terms of capacity for coercive rule-making or the 
ability to affect individual interests. Deliberative democrats have equivocated on whether subjection to coercion or affectedness triggers democratic demands, and I have laid out reasons for favoring the former over the latter. Thinking about how non-electoral representatives can work in either empowered or public spaces forces deliberative democrats to confront this difference and thus tackle an unresolved question in the deliberative literature.

On the other hand, the constructivist turn suggests that representatives mobilize constituencies and shape-shift through the performance of claim-making (Disch 2011; Saward 2014). The ability of deliberative argumentation to alter the interests and positions of (nonelectoral) representatives remains empirically and normatively compelling. Similarly, democrats of all creeds should be concerned about the potential for framing, manipulation, and disingenuousness that can occur through claim-making. The deliberative framework offered here provides a dynamic way to evaluate the democratic credentials of representative claim-making by singular actors (in isolation) and across a system (holistically). Overall, then, crossfertilization helps to shed light on the changing nature of representation, democracy, and legitimate political power - as well as the interactions between all three. 


\section{References}

Abizadeh, Arash. 2008. "Democratic Theory and Border Coercion: No Right to Unilaterally Control Your Own Borders.” Political Theory 36 (1): 37-65.

Abizadeh, Arash. 2012. "On the Demos and its Kin: Nationalism, Democracy, and the Boundary Problem.”American Political Science Review 106 (4): 867-882.

Ankersmit, Frank. 2002. Political Representation. Stanford, CA: Stanford University Press.

Benhabib, Seyla. 1996. “Toward a Deliberative Model of Democratic Legitimacy.” In Democracy and Difference: Contesting the Boundaries of the Political, ed. Seyla Benhabib. Princeton, NJ: Princeton University Press, 67-94.

Bohman, James. 1998. “The Coming Age of Deliberative Democracy.” Journal of Political Philosophy 6 (4): 400-25.

Chauchard, Simon. 2014. "Can Descriptive Representation Change Beliefs about a Stigmatized Group? Evidence from Rural India.” American Political Science Review 108 (2): 403-22.

Disch, Lisa. 2011. "Toward a Mobilization Conception of Democratic Representation.” American Political Science Review 105 (1): 100-14.

Dovi, Suzanne. 2002. "Preferable Descriptive Representatives: Will Just any Woman, Black, or Latino Do?” American Political Science Review 96 (4): 729-43.

Dovi, Suzanne. 2009. “In Praise of Exclusion.” Journal of Politics 71 (3): 1172-1186.

Drahos, Peter and John Braithwaite. 2002. Informational Feudalism: Who Owns the Knowledge Economy. London: Earthscan Publications.

Dryzek, John S. 1996. "Political Inclusion and the Dynamics of Democratization.” American Political Science Review 90 (1): 475-87. 
Dryzek, John S. 2009. "Democratization as deliberative capacity building.” Comparative Political Studies 42 (11): 1379-1402.

Dryzek, John S. 2010. "Rhetoric in Democracy: A Systemic Appreciation.” Political Theory 38 (3): 319-339.

Dryzek, John. S. and Simon Niemeyer. 2008. "Discursive Representation.” American Political Science Review 102 (4): 481-93.

Dür, Andreas and Gemma Mateo. 2014. "Public opinion and interest group influence: How citizen groups derailed the Anti-Counterfeiting Trade Agreement." Journal of European Public Policy 21 (8): 1199-1217.

Eckstein, Harry. 1960. Pressure Group Politics: The Case of the British Medical Association. London: Allen and Unwin.

Elster, Jon. ed. 1998. Deliberative Democracy. Cambridge: Cambridge University Press.

Goodin, Robert E. 2007. "Enfranchising All Affected Interests, and Its Alternatives.” Philosophy \& Public Affairs 35 (1): 40-68.

Grant, Ruth and Robert O. Keohane. 2005. “Accountability and Abuses of Power in World Politics.” American Political Science Review 99 (1): 29-44.

Gutmann, Amy, and Dennis Thompson. 1996. Democracy and Disagreement. Cambridge, MA: Belknap Press.

Habermas, Jürgen. 1996. Between Facts and Norms. Cambridge, MA: MIT Press.

Levine, David S. 2011. “Transparency Soup: The ACTA Negotiating Process and 'Black Box’ Lawmaking.” American University International Law Review 26 (3): 811-837. Macdonald, Terry. 2008. Global Stakeholder Democracy. Oxford, UK: Oxford University Press. 
Manin, Bernard. 1997. The Principles of Representative Government. New York: Cambridge University Press.

Mansbridge, Jane. 2003. "Rethinking Representation." American Political Science Review 97 (4): 515-28.

Mansbridge, Jane. 2009. “The 'Selection Model' of Political Representation.” Journal of Political Philosophy 17 (4): 369-98.

Mansbridge, Jane. 2011. "Clarifying the Concept of Representation.” American Political Science Review 105 (3): 621-30.

Montanaro, Laura. 2012. "The Democratic Legitimacy of Self-Appointed Representatives." Journal of Politics 74 (4): 1094-1107.

Näsström, Sofia. 2015. "Democratic Representation Beyond Election.” Constellations 22 (1): 112.

Owen, David and Graham Smith. 2015. "Survey Article: Deliberation, Democracy, and the Systemic Turn.” Journal of Political Philosophy 23 (2): 213-34.

Parkinson, John, and Jane Mansbridge, eds. 2012. Deliberative Systems: Deliberative Democracy at the Large Scale. Cambridge, UK: Cambridge University Press.

Phillips, Anne. 1995. The Politics of Presence. Oxford: Oxford University Press.

Pitkin, Hanna. 1967. The Concept of Representation. Berkeley: University of California.

Rehfeld, Andrew. 2006. “Towards a General Theory of Political Representation.” The Journal of Politics 68 (1): 1-21.

Rehfeld, Andrew. 2009. "Representation Rethought: On Trustees, Delegates, and Gyroscopes in the Study of Political Representation and Democracy.” American Political Science Review 103 (2): 214-30. 
Rubenstein, Jennifer C. 2014. "The Misuse of Power, Not Bad Representation: Why it is Beside the Point that No One Elected Oxfam.” Journal of Political Philosophy 22 (2): 204-230. Saward, Michael. 2009. "Authorization and Authenticity: Representation and the Unelected." Journal of Political Philosophy 17 (1): 1-28.

Saward, Michael. 2010. The Representative Claim. Oxford, UK: Oxford University Press.

Saward, Michael. 2014. “Shape-Shifting Representation.” American Political Science Review 108 (4): 723-736.

Schäferhoff, Marco, Sabine Campe, and Christopher Kaan. 2009. "Transnational public-private partnerships in international relations: Making sense of concepts, research frameworks, and results." International Studies Review 11 (3): 451-474.

Sell, Susan K. 2013. "Revenge of the 'Nerds': Collective Action against Intellectual Property Maximalism in the Global Information Age.” International Studies Review 15 (1): 67-85.

Urbinati, Nadia. 2000. "Representation as Advocacy: A Study of Democratic Deliberation." Political Theory 28 (6): 758-86.

Urbinati, Nadia and Mark Warren. 2008. "The Concept of Representation in Contemporary Democratic Theory." Annual Review of Political Science 11: 387-412.

Valentini, Laura. 2011. “Coercion and (Global) Justice.” American Political Science Review 105 (1): 205-220

Warren, Mark E. 2012. "When, Where and Why Do We Need Deliberation, Voting and Other Means of Organizing Democracy? A Problem-based Approach to Democratic Systems.” Paper presented at the annual meeting of the American Political Science Association, September 2012. 
White, Jonathan and Lea Ypi. 2011. “On Partisan Political Justification.” American Political Science Review 105 (2): 381-397.

Young, Iris Marion. 2000. Democracy and Inclusion. Oxford: Oxford University Press. 
Appendix A: Public Non-Electoral Representatives

\begin{tabular}{|l|l|}
\hline Public Group & Representative Claim \\
\hline Arbeiterkammer (AK) & Yes - Explicit \\
\hline Asociación de Usuarios de Internet, Peru (AUI) & Yes - Implicit \\
\hline Association of Commercial Television in Europe (ACT) & Yes - Explicit \\
\hline Association of Research Libraries (ARL) & Yes - Explicit \\
\hline ATTAC Germany & Yes - Implicit \\
\hline Australian Copyright Council & Yes - Explicit \\
\hline Australian Digital Alliance & Yes - Explicit \\
\hline Avaaz & Yes - Implicit \\
\hline BIEM (Mechanical Rights Society) & Yes - Explicit \\
\hline British American Tobacco (BAT) & Yes - Implicit \\
\hline Center for Democracy and Technology (CDT) & Yes - Implicit \\
\hline Center of the Picture Industry (CEPIC) & Yes - Explicit \\
\hline Coalition for Intellectual Property Rights (CIPR) & Yes - Implicit \\
\hline Consumers International (CI) & Yes - Explicit \\
\hline Content Creators Coalition (CCC) & Yes - Explicit \\
\hline Content Creators Coalition NYC & Nes - Explicit \\
\hline Corporate Europe Observatory (CEO) & Yes - Implicit \\
\hline Doctors without Borders (MSF) & \\
\hline Electronic Frontier Foundation (EFF) & No \\
\hline EuroCommerce & (Cicit \\
\hline
\end{tabular}




\begin{tabular}{|l|l|}
\hline European and International Booksellers Federation (EIBF) & Yes - Explicit \\
\hline European Newspaper Publishers' Association (ENPA) & Yes - Explicit \\
\hline Gesamtverband Textil + Mode & Yes - Explicit \\
\hline Initiative für netzfreiheit (The Network Freedom Initiative) & Yes - Implicit \\
\hline Interactive Software Federation of Europe (ISFE) & Yes - Explicit \\
\hline International Federation of Library Associations and & Yes - Explicit \\
Institutions (IFLA) & \\
\hline International Fragrance Association (IFRA) & Yes - Explicit \\
\hline Internet Service Providers Association of Ireland (ISPAI) & Yes - Explicit \\
\hline Knowledge Ecology International (KEI) & Yes - Implicit \\
\hline La Quadrature du Net & Yes - Implicit \\
\hline Ochranný svaz autorsḱ́ (Protective Union for Authors) & Yes - Explicit \\
\hline Open Data Network & Yes - Explicit \\
\hline Open Rights Group (ORG) & Yes - Explicit \\
\hline Organización Profesional de Editores de Música & Yes - Explicit \\
\hline Oxfam & Yes - Implicit \\
\hline Public Knowledge & Yes - Implicit \\
\hline Publishing Ireland (Foilsiú Éireann) & Yes - Explicit \\
\hline Spitzenorganisation der Filmwirtschaft (SPIO) & Yes - Implicit \\
\hline Torrent Freak (TF) & Explicit \\
\hline Trans-Atlantic Business Council & \\
\hline
\end{tabular}


Appendix B: Empowered Non-electoral Representatives

\begin{tabular}{|l|l|}
\hline Empowered Group & Representative Claim \\
\hline (Business) Software Alliance (BSA) & Yes - Explicit \\
\hline Consumer Electronics Association (CEA) & Yes - Explicit \\
\hline Coalition for Intellectual Property Rights (CIPR) & Yes - Implicit \\
\hline International AntiCounterfeiting Coalition (IACC) & No \\
\hline International Federation of the Phonographic Industry (IFPI) & Yes - Explicit \\
\hline International Intellectual Property Alliance (IIPA) & Yes - Explicit \\
\hline Motion Picture Association of America (MPAA) & Yes - Explicit \\
\hline Software and Information Industry Association (SIIA) & Yes - Implicit \\
\hline PhRMA & Yes - Explicit \\
\hline Recording Industry Association of America (RIAA) & Yes - Explicit \\
\hline
\end{tabular}

